\title{
【論文】
}

\section{最終処分場の適正化に向けた調査と対策 II}

\author{
—保有水等の流出の観点から——
}

宮原哲 也** 八村智 明* . 大 野 博 之 ${ }^{* *}$. 小坂 英 輝 ${ }^{* *}$ 細 野 賢 一 *** . 山内一志* · 中 稔 ${ }^{* * * *}$

【要 旨】既設の一般廃棄物最終処分場において不適正な状況を改善するための適正化事業を行った。 不適正な最終処分場では，埋立地からの保有水等の流出が懸念材料となることが多く，この最終処分場 においても, 周辺環境の保全の観点からの調査を実施し, その調査を用いた数值シミュレーション等を 実施した。

本研究の結果, 廃棄物埋立地内の保有水等の水位が高いとき, 現地の地下水位や水質観測の結果と整 合する埋立地外への保有水等の流出が生じる可能性のあることが明らかとなった。この恒久対策として, 埋立地内の水理ポテンシャルを周辺地下水のそれよりも下げる工法（ウォーターバリア工法），たとえ ば集水井工の設置が有効であることが数值シミュレーションにより示された。この工法は, 周辺環境の 保全に有効なだけでなく，力学的安定性にも有効な工法であり，施工性・コス卜面でも優れている。

キーワード：最終処分場, 適正化調査, 物理探査, 数值シミュレーション, ウォーターバリア工法

\section{1. は じめに}

一般廃棄物最終処分場や産業廃棄物最終処分場の中に は, 現行の廃棄物の処理及び清掃に関する法律（廃棄物 処理法）に基づく基準省令が適用される以前に設置され た稼働中の最終処分場も数多く存在し, 場合によっては 「一般廃棄物の最終処分場及び産業廃棄物の最終処分場 に係る技術上の基準を定める省令（以降，〔基準省令〕 と呼ぶ)」に適合させた適正化を行わなければならない 事例もみられる1)。

筆者らは，基準省令に適合しない最終処分場の適正化 事業に取り組んできた。その一例として, 糸魚川市一般 廃棄物最終処分場の力学的安定性について示した ${ }^{2)}$ が,

原稿受付 2018.5.7 原稿受理 2018. 12.17

* (一財) 日本環境衛生センター 西日本支局

*** (侏)環境地質

**** (侏地層科学研究所 地下環境事業グループ

***** 香川大学 創造工学部

連絡先：干 210-0014 神奈川県川崎市川崎区貝塚 1 丁目 4-15-203 秼環境地質 大野 博之 E-mail : ohno@kankyo-c.com
元々, この最終処分場の不適正は, ばいじん埋立処分に 係る判定基準を超えた水銀を含む廃棄物（水銀含有廃棄 物）を埋め立てたことにある。こうした水銀含有廃棄物 により污染された保有水等が最終処分場の埋立地外に流 出し, 周辺の環境に影響を及ぼす可能性があることから 適正化事業が始まった。

不適正な最終処分場で最も問題となるのは, こうした 周辺環境への影響である ${ }^{3)}$ 。最終処分場は, 基準省令等 にも示されるように, 重金属等の有害物質を含む保有水 等による污染を防止し周辺環境を保全する必要がある。 このため, 基準省令には, “浸出液による公共の水域及 び地下水の污染を防止するため”に遮水工や保有水等集 排水設備等を適切に設ける必要のあることが示されてい る。

不適正最終処分場については,「不適正処分場におけ る土壌污染防止対策マニュアル (案) (以降, 〔対策マ ニュアル案」と呼ぶ) 」 $\rfloor^{4)} \mathrm{NPO}$ 法人最終処分場技術 システム研究協会5)等により, 適正化のための対策工法 がまとめられている。しかし, 適正化に向けた調査・検 討・評価方法については, 詳細な記述はない。

実際の最終処分場では, 遮水工等による最終処分場の 
遮断機能の不備が生じる場合もある ${ }^{1)}$ 。最終処分場は, 廃棄物の貯留機能の他に, 廃衰物からの有害物質の漏え いを遮断する機能（遮断機能）をもっていなければなら ず，筆者らが取り組んだ糸魚川市一般廃棄物最終処分場 でも, 最終処分場のもつ遮断機能の不備が課題となった。 糸魚川市一般廃棄物最終処分場 ${ }^{6)}$ は, 2008 (平成 20) 年 11 月 19 日に新潟県による一般廃棄物処理施設機能検 査において, ごみ処理施設 (炭化方式) の薬剤処理後の ばいじん（水銀含有廃棄物）から基準值を超える水銀ま たはその化合物が検出され，2009 (平成 21) 年 1 月 30 日にごみ処理施設の改善指導を受けた。このため, 過去 に実施した検査から得られたデー夕を再度調査した結果, 2003 (平成 15) 年 8 月の検査から基準值を超えるデー夕 が 8 回あったことが明らかとなった。これを受けて, 2009 (平成 21 ) 年 3 月, 最終処分場への廃棄物の搬入が 中止された。その後, 筆者らの提案により 2009 (平成 21) 年 8 月〜 2010 (平成 22) 年 5 月にかけ応急対策（排 水管敷設等）を実施し，それと並行して適正化恒久対策 のための調査, 対策工の提案, 設計が行われた。その後, 対策の実施後に廃棄物の埋め立ては行わず廃止に向けた 手続きが行われ，2018 (平成 30) 年 4 月に廃止された。 なお，基準值を超えるような水銀を含んだ保有水等は検 出されておらず，周辺地下水も污染されていない。

本論では, この最終処分場における適正化のための調 査とその結果の判断と対応について, 周辺環境への影響 の一つである保有水等の流れの観点から論じるとともに, 環境保全対策の一つとして, ウォーターバリア工法につ いて論じる。

\section{2. 対象最終処分場と調査方法}

\section{1 対象最終処分場の概要}

本論で取り上げる最終処分場は, 新潟県糸魚川市の一 般廃棄物最終処分場である。

この最終処分場の諸元は以下のとおりである。

・埋立開始年月：1975（昭和 50) 年 9 月

·埋立面積 : 40,000 $\mathrm{m}^{2}$

·埋立容量 : 400,000 $\mathrm{m}^{3}$

·埋立物：埋立ごみ, ごみ処理施設（炭化方式）の飛 灰・残椬, し尿処理污泥の焼却灰

·水処理能力: 能力 $200 \mathrm{ton} /$ 日, 調整槽なし

- 埋立地構造: 保有水等集排水施設（底面暗渠）およ び雨水集排水施設あり。遮水工なし（透水係数が $10^{-7}$ $\mathrm{m} / \mathrm{sec}$ 未満の地盤) および地下水集排水施設なし

\section{2 保有水等の流れを解明するための地質工学的調査}

筆者らは, 適正化応急対策の実施前後において, その 後に実施する適正化のための恒久対策についての方向性 を示すための調査とその結果の分析・評価を実施した。 宮原ら ${ }^{2)}$ では, 埋立地内の保有水等の水位が示されてい るが, ここでは, 保有水等や周辺地下水の流れを解明す

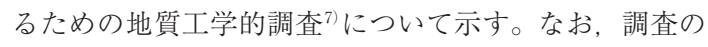
実施内容と時期を表 1 に示す。

\section{2 .1 地質調査}

一般的な資料調査，地形調査，地表地質踏査および現 場透水試験を含むボーリング調査等の地質調査を実施し た（図 1)。地質調査は，ボーリング調査も含め 2009 (平成 21) 年 8〜9 月に実施し, ボーリング No. 4 6 孔 の廃棄物層を対象に現場透水試験を実施した。また, 資

表 1 一般廃棄物最終処分場の適正化のための地質工学的調査一覧表

\begin{tabular}{|c|c|c|c|}
\hline 調査名 & 調査内容（数量等） & 調査期間 & 備考 \\
\hline 資料調査 & $\begin{array}{l}\text { 過去の調査報告書, 設計図, 地形図等の収集整理 } \\
(1992 \sim 1994 \text { (平成 4 6) 年の調查結果含む) : 一式 }\end{array}$ & 2009 (平成 21 ) 年 $6 \sim 7$ 月 & \\
\hline 地形調査 & $\begin{array}{l}\text { 過去の空中写真, 衛星画像, 旧版地形図等を用いた } \\
\text { 地形判読等 : 一式 }\end{array}$ & 2009 (平成 21 ) 年 $7 \sim 8$ 月 & \\
\hline 地表地質踏査 & 最終処分場周辺 : 約 $2,000,000 \mathrm{~m}^{2}$ & 2009 (平成 21) 年 8～9 月 & \\
\hline ボーリング調査 & $\begin{array}{l}\text { No. 1 14 孔のオールコアボーリングと標準貫入試 } \\
\text { 験：計 } 175 \mathrm{~m}\end{array}$ & 2009 (平成 21 ) 年 8 9 月 & \\
\hline 現場透水試験 & No. 4 6 孔の透水試験：3 区間 & 2009 (平成 21) 年 9 月 & \\
\hline 地下水位観測 & $\begin{array}{l}\text { No. 1, 2, 4, 6, 10〜14 孔: 自動計測 } \\
\text { No. 3, 5, 7〜9 孔 : } 1 \text { か月ごとの観測 }\end{array}$ & $\begin{array}{l}2009 \text { (平成 } 21 \text { ) 年 } 11 \text { 月 } \\
2010 \text { (平成 } 22 \text { ) 年 } 9 \text { 月 }\end{array}$ & \\
\hline イオン分析 & $\begin{array}{l}\text { ボーリング No. 1〜14 孔 } \\
\text { 集水桝 No. 15 } \\
\text { 表流水・湧水 S-1 S-17, P-1〜P2 }\end{array}$ & $\begin{array}{l}2009 \text { (平成 } 21 \text { ) } 21 \text { 年 } 9 \text { 月 } \\
2010 \text { (平成 } 22 \text { ) 年 } 4 \text { 月 }\end{array}$ & \\
\hline 化学分析 & $\begin{array}{l}\text { 地下水の重金属等の分析（地下水項目分析）：No. } \\
1 \sim 4, \text { No. } 7, \text { No. } 12 \text { 孔 }\end{array}$ & 2010 (平成 22 ) 年 $4 \& 8$ 月 & 保有水等も含めた地下水 \\
\hline 比抵抗電気探査 & $\mathrm{D}$ 測線 : $70 \mathrm{~m}$ & $\begin{array}{l}2009 \text { (平成 } 21) 21 \text { 年 } 8 \text { 月 } \\
2010 \text { (平成 } 22 \text { ) 年 } 6 \text { 月 }\end{array}$ & \\
\hline
\end{tabular}




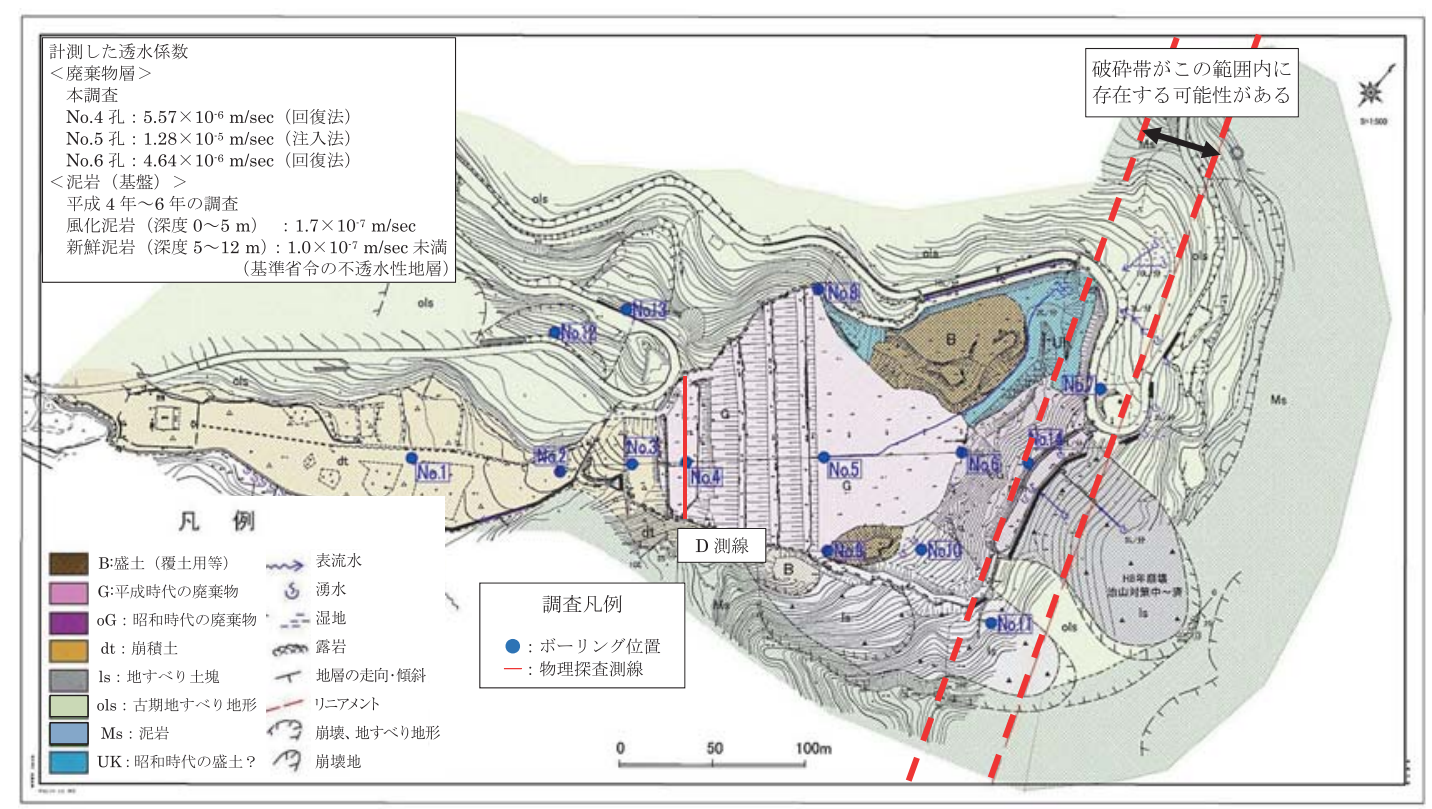

図 1 一般廃棄物最終処分場および周辺の地質状況, およびボーリング調査・物理探査の実施位置図

料調査では，1992１994（平成 4～6) 年にかけて実施さ れた地質調査結果等も取りまとめた。

\section{2 .2 物理探査}

物理探査としては, 二次元比抵抗電気探査 (比抵抗 法) ${ }^{8)}$ を, 適正化応急対策実施前後の 2009 (平成 21) 年 8 月と 2010 (平成 22) 年 6 月に実施した。埋立廃棄物の ような堆積層では, 粘土鉱物も含まず, 間隙率も花崗岩 等のように小さくないためにアーチーの式が成立す る $^{2,8)}$ ので, 比抵抗分布の変化より廃棄物層内の含水状 況の変化を把握することが可能である。特に, 保有水等 の漏えいを把握するために, 図 1 に示す D 測線で応急 対策実施前後の比抵抗電気探査を行った。

\section{2 .3 モニタリング調査}

応急対策実施前後において, 保有水等を含めた地下水 および表流水（湧水も含む）を 2009 (平成 21) 年 9 月と 2010 (平成 22) 年 6 月に採取し, イオン分析を行った。 これによりイオン型を求め, 地下水や表流水等の性質を 捉えた。また, 地下水については, 2010 (平成 22) 年 4 月と 8 月に, 重金属等の地下水項目の化学分析も行うと ともに, 宮原ら ${ }^{2)}$ に示されるように, 埋立地内も含めた 最終処分場の地下水位のモニタリングも行った。

\section{3. 調 査 結 果}

\section{1 水文地質状況}

地質調査結果に基づいた地質分布図を図 1 に示す。
最終処分場周辺の基盤は第三紀の泥岩で, 透水性は極 めて低い。この泥岩の透水係数は, 1992１994 (平成 4 6) 年の調査により, 最大深度 $5 \mathrm{~m}$ までの風化泥岩におい ては $1.7 \times 10^{-7} \mathrm{~m} / \mathrm{sec}$ 程度であるが, それ以深の未風化 泥岩では $1.0 \times 10^{-7} \mathrm{~m} / \mathrm{sec}$ 未満で, その未風化泥岩の分 布は深度 $12 \mathrm{~m}$ まで確認されており, 基準省令のいう不 透水性地層である。このため, この最終処分場には遮水 工は設置されていない。また, 廃棄物層は平成時代に埋 め立てられた廃棄物で, $4.64 \times 10^{-6} \sim 1.28 \times 10^{-5} \mathrm{~m} / \mathrm{sec}$ であることが, 今回の現場透水試験で求められた（図 1)。 また, 地形調査等から, 処分場の北部を北西一南東方 向に横切るリニアメント (線状模様) が抽出できる。こ のリニアメントは, 地表踏査では明瞭な断層を示してい ないので，断層の正確な位置を特定はできない。一方， 図 1 の右上部に $10 \mathrm{~L} /$ 分の湧水のある湿地が形成されて いる。地形調査で見られるリニアメントは, 割れ目の密 集部あるいは断層破砕帯（以降，〔破砕帯〕と呼ぶ）で あるために形成された可能性があり,このリニアメント として示される破砕帯により透水性が高くなっているた めに湿地が形成された可能性もある。すなわち, その湿 地を含めた, 図に示す範囲に破砕帯が存在する可能性が ある。この図に示されるように, この破砕帯は, 昭和時 代の廃棄物の直下を通る可能性があり, 水ミチとなるこ とが懸念される。すなわち, 昭和時代の廃棄物の保有水 等が最終処分場外へ流出し, 周辺環境を污染する可能性 を検討する必要がある。 


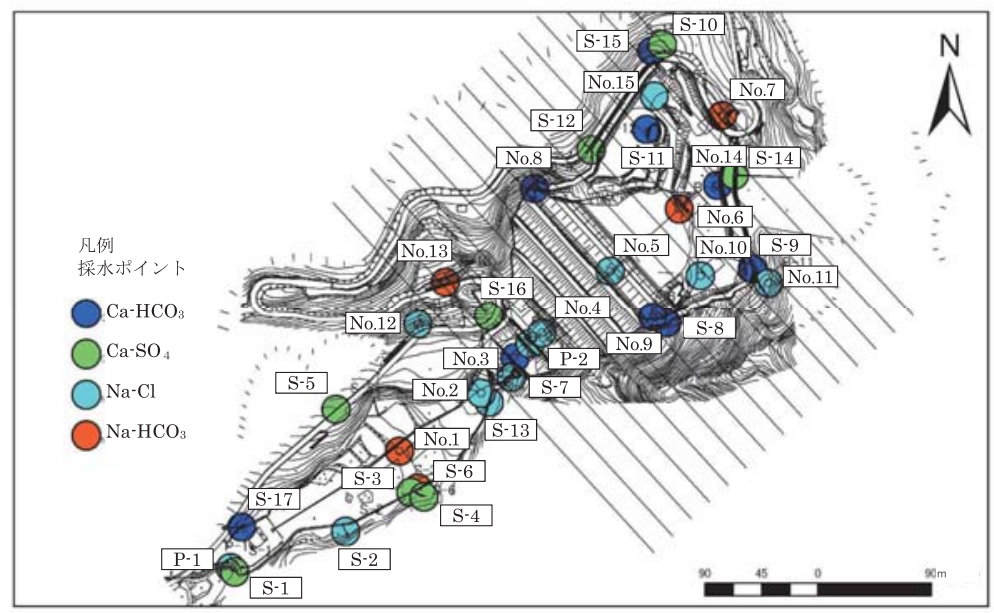

(a) 実施前のイオン型分布 (2009 (平成 21$)$ 年 9 月)

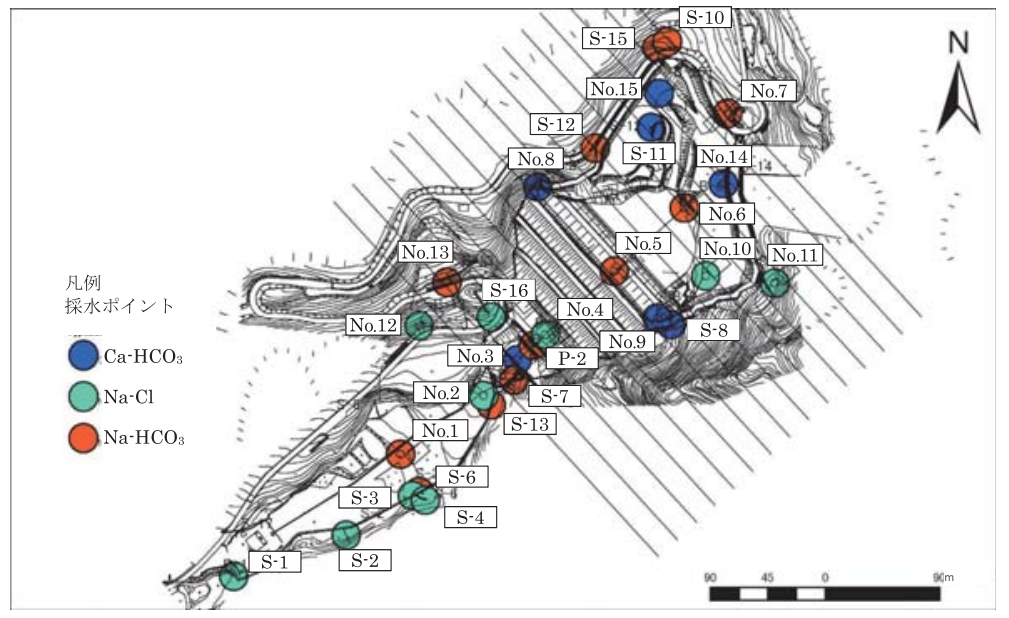

（b）実施後のイオン型分布（2010（平成 22）年 4 月）：実施前と異なり採水できなかった箇所有 注：図中の「No」はボーリング孔番号（地下水採水箇所），「S-」「P-」は表流水・湧水採水箇所番号

図 2 適正化応急対策実施前後のイオン分析結果

\section{2 イオン分析・化学分析の結果}

応急対策実施前後の地下水等のイオン分析結果を図 2 に示す。この結果は，イオン分析により作成できるトリ リニアダイアグラムより 4 つの類型に分類したもの $\left(\mathrm{Ca}-\mathrm{HCO}_{3}\right.$ 型（アルカリ土類炭酸塩）, $\mathrm{Na}-\mathrm{HCO}_{3}$ 型（ア ルカリ炭酸塩), $\mathrm{Ca}-\mathrm{SO}_{4}$ 型 (アルカリ土類非炭酸塩), $\mathrm{Na}-\mathrm{Cl}$ 型（アルカリ非炭酸塩）の 4 種 $)^{9)}$ を平面上にプ ロットしたものである。なお，それぞれの型には地下水 等の特徵が現れる ${ }^{10)}$ 。

この図に示されるように, 周辺のボーリング孔の地下 水は一般の井戸水にみられる $\mathrm{Ca}-\mathrm{HCO}_{3}$ 型が多いが, 対 策実施前後ともにNo. 12 孔は $\mathrm{Na}-\mathrm{Cl}$ 型である。周辺の 地下水の化学分析の結果からは, ひ素が 2010 (平成 22) 年 4 月にボーリング No. 4 孔で $0.013 \mathrm{mg} / \mathrm{L}$ と環境基準
(0.01 mg/L 以下) を若干超えたが, その他の水銀や鉛 等の重金属等はN No. 4 孔も含め環境基準值以下である (たとえば, $\mathrm{Hg}: 0.00005 \mathrm{mg} / \mathrm{L}$ 未満, $\mathrm{Pb}$ : 最大 0.009 $\mathrm{mg} / \mathrm{L})$ 。

$\mathrm{Na}-\mathrm{Cl}$ 型は埋立廃棄物層内の保有水等や海水によくみ られるイオン型であり, 廃棄物層内の No. 4 から埋立地 北西側の湧水の水である S-16（応急対策実施後のみ $\mathrm{Na}-\mathrm{Cl}$ 型), そして, 地すべり土塊内の No. 12 とその下 流の No. 2 といった一連の水が $\mathrm{Na}-\mathrm{Cl}$ 型である。すなわ ち. No. $4 \rightarrow($ S-16) $\rightarrow$ No. $12 \rightarrow$ No. 2 といった水の流れ のある可能性を示唆している。こうした水の流れが応急 対策実施後も存在するのであれば，現在は重金属等によ り污染されてはいないものの, 今後適切な対策を行わな ければ，埋め立てられた水銀含有廃棄物等からの有害物 
質の漏えいが懸念される。

一方，水文地質状況で明らかにしたように，昭和時代 の廃棄物の直下に破砕帯が存在し, 水ミチとなっている 可能性がある。この破砕帯近傍で昭和時代の廃棄物内の No. 10 の地下水は $\mathrm{Na}-\mathrm{Cl}$ 型であり, 推定される破砕帯 の範囲内では, 地すべり土塊中の No. 11 が Na-Cl 型で ある。したがって, この破砕帯は水ミチとなっている可 能性があるが, このイオン分析だけでは断定することが できない。仮に，水ミチとなっている場合には保有水等 が漏えいし, 昭和時代の廃棄物の除去も必要となる場合 が考えられる。

したがって，今後の恒久対策には，以上の点を明らか にしておく必要があることから, 後述する三次元飽和・ 不飽和浸透流解析を行った。

\section{3 比抵抗電気探査結果}

図 3 に適正化応急対策実施前後の比抵抗電気探査の結 果を示す。これはNo. 4 孔を通る横断面である（位置は

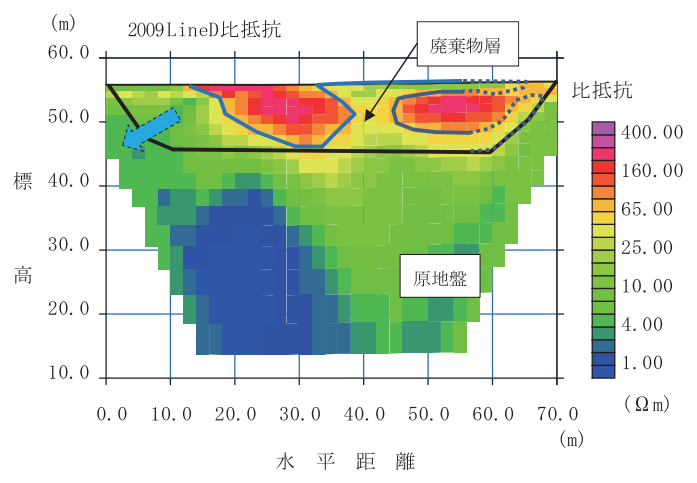

(a) 適正化応急対策実施前の比抵抗分布

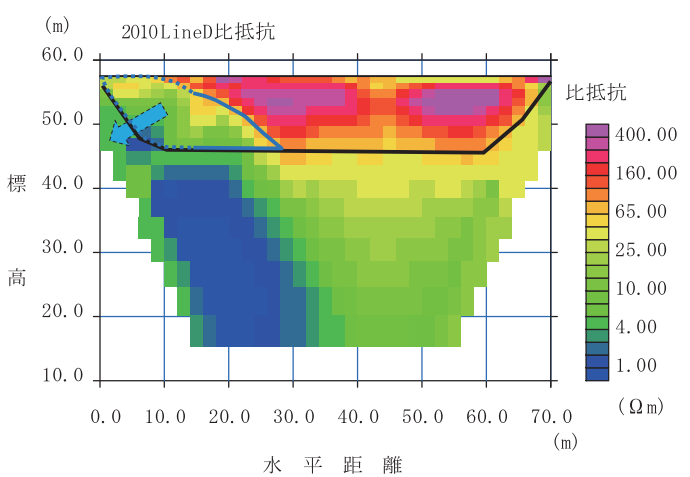

（b）適正化応急対策実施後の比抵抗分布

青実線 : 高含水域（信頼度大), 青破線 : 高含水域（信頼度小） 青矢印：保有水等の埋立地外への流出（可能性）

黒線：廃棄物層と原地盤との境界

図 3 適正化応急対策実施前後の比抵抗分布の変化 (D 測線)
図 2 の D 測線)。

図 3 の黒線は, ボーリングNo.4のコア観察結果と, 過去の設計図や地形図等から判断した廃棄物層と基盤と の境界である。宮原ら ${ }^{2)}$ は, この図の比抵抗電気探査の 信頼性の高い範囲を, 水平距離 15〜30 m, 標高 46〜53 $\mathrm{m}$ の部分とし, この範囲の $65 \Omega \mathrm{m}$ 以下の低比抵抗を示 す部分は高含水域であることを示している。したがって, この範囲は応急対策実施前後ともに高含水域となってい ると判断できる。なお, この高含水域とは, 飽和度 80 $\%$ 程度以上 ${ }^{2)}$ の部分であり, 保有水面とは異なる。

比抵抗電気探査結果の信頼性は高くないが, 何らかの 含水状態の違いを表している可能性がある区間として, 水平距離 5 $15 \mathrm{~m}$ がある。この区間にも比抵抗 $65 \Omega \mathrm{m}$ 以 下の低比抵抗部が分布し (図 4 の青破線), 高含水となっ ている可能性がある。したがって, 埋立地内から外への 流れが生じる可能性を検討すべきことを示唆している。

\section{4. 恒久対策検討のための解析}

\section{1 三次元飽和・不飽和浸透流解析の意義}

適正化事業においては, 現状の現象を適切に把握する とともに，施工性やコスト面を勘案した実用性および社 会的要請を考慮した適正化恒久対策を実施しなければな らない。

前述したように，イオン分析や比抵抗電気探査の結果 等から, 応急対策実施後においても埋立地内の保有水等 が埋立地外へ流出している可能性があることが示唆され た。

保有水等の埋立地外への流出状況をより適切に解明す るためには, 比抵抗電気探査では探査上の限界がある。 すなわち, 現在よりも測線長を伸ばし信頼できる探査範 囲を広げようとする場合, 埋立地外の急峻な地形や, 風 化変質した泥岩等の複雑な地質の影響を受け, 適切な比 抵抗分布を得るためには二次元解析では限界があり，信 頼性の低い比抵抗分布図しか得られない可能性が高い ${ }^{8)}$

また, 地下水等のイオン分析や地下水項目分析では, 新たな地下水観測孔等を設け, 数年にわたる長期モ二夕 リングが必要となる。しかし, 恒久対策を行うための時 間的制約等があるため, 長期モニタリングは現実的では ない。

これに対して, 三次元飽和・不飽和浸透流解析では, 現状の取得データだけで保有水等を含めた地下水につい て立体的に恒久対策前後の状況を捉えることができる。 また，流速べクトルや水理ポテンシャルを断面や平面方 向で任意に捉え, 対策工の効果等も検討できる。した がって, 現在取得している調査結果から妥当な保有水等 


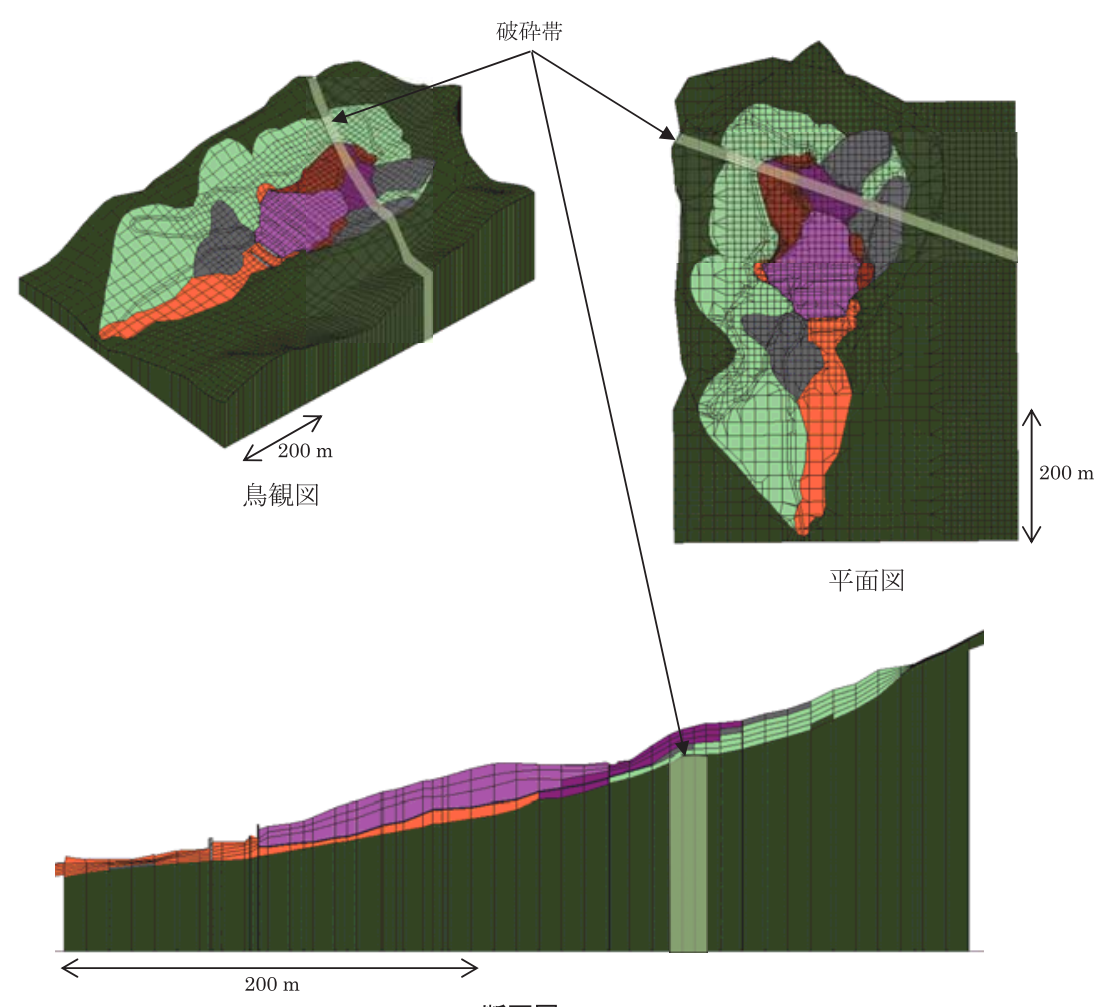

断面図

解析の境界条件 :

非流動境界条件（流束 $=0$ )

（尾根部を境界として一つの流域と仮定）

\begin{tabular}{|c|c|}
\hline \multicolumn{2}{|c|}{ 凡 例 } \\
\hline 記号 & 地層名 \\
\hline G & 廃棄物 (平成) \\
\hline$O G$ & 廃萊物（昭和） \\
\hline B & 盛土 \\
\hline $\mathrm{dt}$ & 崩積土 \\
\hline Is & 地すべり土塊 \\
\hline ols & 古期地すべり土塊 \\
\hline Ms & 第三紀 泥岩 \\
\hline コンクリート & コンクリート \\
\hline
\end{tabular}

注）破砕帯は泥岩の部分にのみ存在するが，位置がわかりやすいように，鳥瞰図および平面図は泥岩以外の部分にも色塗りしている

図 4 最終処分場周辺の地下水数值解析のための水文地質モデル

の流出状況を解明するためには，FEM（Finite Element Method：有限要素法）による三次元飽和・不飽和浸透 流解析が有効であると判断される。

\section{2 解析モデルと同定解析}

解析モデルとしては, 図 4 に示すような水文地質モデ ルを設定した。これらのモデルは，ボーリング調査等の 地質調査の結果（資料調査や地形調査の結果も含む）よ り設定した。地すべり土塊, 古期地すべり土塊, 崩積土 の透水係数は現場計測等では得られていない。一方，前 述したように破砕帯の位置は明瞭ではないので，漏えい 経路となりうる位置として昭和時代の廃棄物の直下を通 ると仮定することとした。

以上のことから，未知の透水係数を設定するための同 定解析を定常流で実施した。同定解析では, 現場計測さ
れた水位（図 1 のボーリング No. 1〜14の水位）に フィッティングするように, 地すべり土塊, 古期地すべ り土塊, 崩積土, 破砕帯の透水係数や破砕帯の有無等を 変化させ, トライアンドエラーにより同定した（表 2 お よび図 5 参照)。なお，昭和時代の廃棄物および古期地 すべり土塊は，それぞれ時間経過により締め固まってい るため, 平成時代の廃棄物や地すべり土塊よりも小さい 透水係数を設定した。

同定解析により最も計測結果と一致した結果を図 5 に 示す。この図に示すように, 同定解析結果と計測結果と がほぼ一致し，表 2 に示す透水係数が設定できる。廃棄 物 (平成) 層の計測透水係数は, 図 1 に示されるように $4.64 \times 10^{-6} \sim 1.28 \times 10^{-5} \mathrm{~m} / \mathrm{sec}$ であるが，注入法は回復 法より透水係数が大きく算出される傾向があり, 回復法 のほうが自然状態に近い值を示すものと考えられる。し 
表 2 定常解析における同定解析と最終的な設定透水係数

. 境界条件

降雨強度 : $0.011334 \mathrm{~m} /$ day, 降雨浸透率 0.4

(糸魚川アメダスデータ 2009 (平成 21) 年 11 月 15 日〜2010 (平成 22) 年 5 月 11 日の一日平均雨量より設定)

·定常解析結果と計測結果との残差からみた最適ケース

○破砕带なしケース：地すべり土塊（ls）, 古期地すべり土塊（ols）, 崩積土（dt）の透水係数を数ケース設定

○破砕帯ありケース：地すべり土塊 (ls), 古期地すべり土塊 (ols), 崩積土 (dt) の透水係数の他, 廃棄物 (平成) $(\mathrm{G})$ ，廃棄物（昭和） $(\mathrm{oG})$, 破砕带 $(F)$ の透水係数も数ケース設定

\begin{tabular}{|l|c|l|}
\hline \multicolumn{1}{|c|}{ 解析ケース } & 残差の絶対值平均 $\Delta_{\mathrm{a}}$ & \multicolumn{1}{c|}{ 備 考 } \\
\hline (1)破砕帯なし & $1.25 \mathrm{~m}$ & それぞれの解析ケースで最も \\
\hline (2)破砕帯あり $: 1 \times 10^{-3} \mathrm{~m} / \mathrm{sec}$ & $1.30 \mathrm{~m}$ & 残差が小さい透水係数の組み \\
\hline (3)破砕帯あり $: 1 \times 10^{-6} \mathrm{~m} / \mathrm{sec}$ & $1.16 \mathrm{~m}$ & 合わせのときの $\Delta_{\mathrm{a}}$ \\
\hline
\end{tabular}

$\Delta_{a}=\sum_{i=1}^{n}\left|h_{a_{i}}-h_{m_{i}}\right| / n$

ここで, $h_{a}$ : 解析結果の地下水位, $h_{m}$ : 観測結果の地下水位, $n:$ 観測孔の数

·最終的な設定透水係数

\begin{tabular}{|c|c|c|c|}
\hline 色（記号） & 地層区分名 & 最終設定透水係数 & 計測透水係数等 \\
\hline G & 廃棄物（平成） & $7.5 \times 10^{-7}[\mathrm{~m} / \mathrm{sec}]$ & $10^{-6}$ オーダー $[\mathrm{m} / \mathrm{sec}]$ \\
\hline $\mathrm{oG}$ & 廃棄物（昭和） & $5.0 \times 10^{-7}[\mathrm{~m} / \mathrm{sec}]$ & 廃棄物 G よりも小さい值を想定 \\
\hline B & 盛土 & $1.0 \times 10^{-6}[\mathrm{~m} / \mathrm{sec}]$ & 砂ーシルトの比較的低い透水係数を想定 \\
\hline $\mathrm{dt}$ & 崩積土 & $5.0 \times 10^{-7}[\mathrm{~m} / \mathrm{sec}]$ & - \\
\hline is & 地すべり土塊 & $5.0 \times 10^{-6}[\mathrm{~m} / \mathrm{sec}]$ & - \\
\hline ols & 古期地すべり土塊 & $2.0 \times 10^{-7}[\mathrm{~m} / \mathrm{sec}]$ & 地すべり土塊 ls よりも小さな值を想定 \\
\hline Ms & 第三紀 泥岩 & $1.0 \times 10^{-7}[\mathrm{~m} / \mathrm{sec}]$ & $10^{-7}$ 未満 $[\mathrm{m} / \mathrm{sec}]$ \\
\hline コンクリート & $\begin{array}{l}\text { コンクリート } \\
\text { アスファルト } \\
\end{array}$ & $1.0 \times 10^{-9}[\mathrm{~m} / \mathrm{sec}]$ & 実質上不透水を想定 \\
\hline 暗渠等 & 暗渠, 水抜きボーリング & $1.0 \times 10^{-3}[\mathrm{~m} / \mathrm{sec}]$ & 磁の透水係数を想定 \\
\hline $\mathrm{F}$ & 破砕帯 & $1.0 \times 10^{-6}[\mathrm{~m} / \mathrm{sec}]$ & - \\
\hline
\end{tabular}

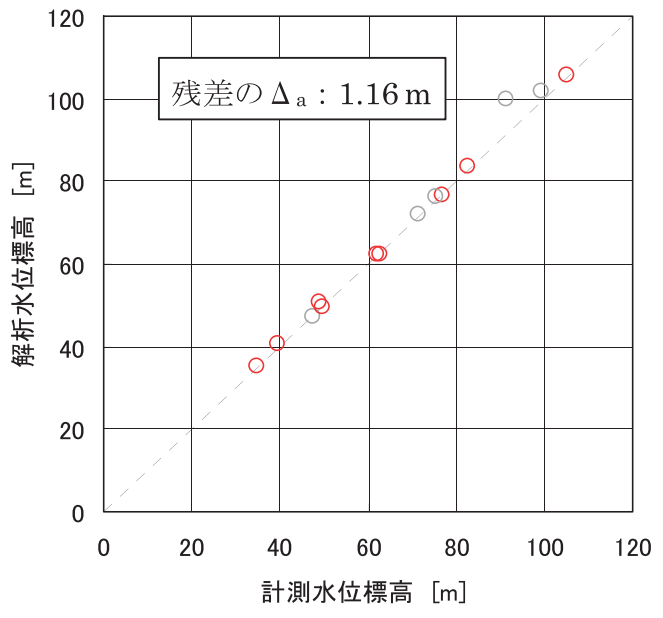

図 5 破砕带の透水係数 $1 \times 10^{-6} \mathrm{~m} / \mathrm{sec}$ のときの残差が最 も小さくなる透水係数の組み合わせの場合の同定 解析の結果 (表 2 の最終的な設定透水係数の場合)

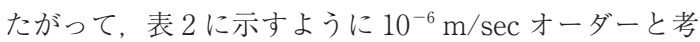
えられる。表 2 に示したように, 同定された廃棄物の透 水係数は現地計測值よりも小さくなったが, 廃棄物の透
水係数は $10^{-9} \sim 10^{-4} \mathrm{~m} / \mathrm{sec}$ の範囲にあり, その多くは $10^{-7} \sim 10^{-5} \mathrm{~m} / \mathrm{sec}$ の範囲である ${ }^{11)} こ と, 10^{-7} \sim 10^{-6}$ $\mathrm{m} / \mathrm{sec}$ の透水係数は同じ「透水性の低い」地盤と捉え られること ${ }^{12)}$ から, 計測值は局所的な透水性を表したも のであり, 廃棄物層全体は計測值よりも小さい值と考え られる。また, 破砕帯が存在しているほうが残差の絶対 值平均が小さくなることは, 図 1 に示される湿地の存在 も破砕帯の影響であることを裏づけるものと考えられる。 なお, 難透水層と透水層が複雑に重なるような, より 混然とした水文地質構造であれば非定常流で解析を行う べきであるが, 対象地は難透水層の泥岩が広く分布する 地質構造であること, 各計測地点での計測水位と解析水 位との残差の絶対值平均は $1.16 \mathrm{~m}$ と極めて小さいこと などから，この定常流による同定解析で十分と判断した。

以上のことから, 最終的な透水係数の設定值は, 表 2 に示すような值であると判断した。

\section{3 非定常による恒久対策工実施前の解析結果}

同定解析の結果を基に, 図 6 に示す非定常解析を行っ た。ここでは, 糸魚川の降雨量を考慮し, 最大 0.15 


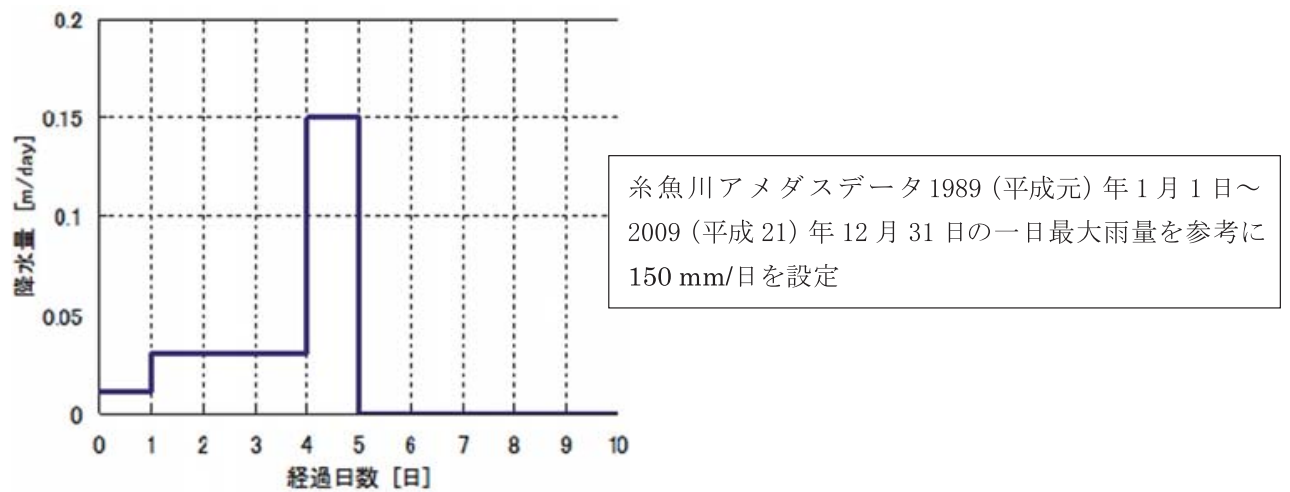

(a) 非定常の入力降雨強度
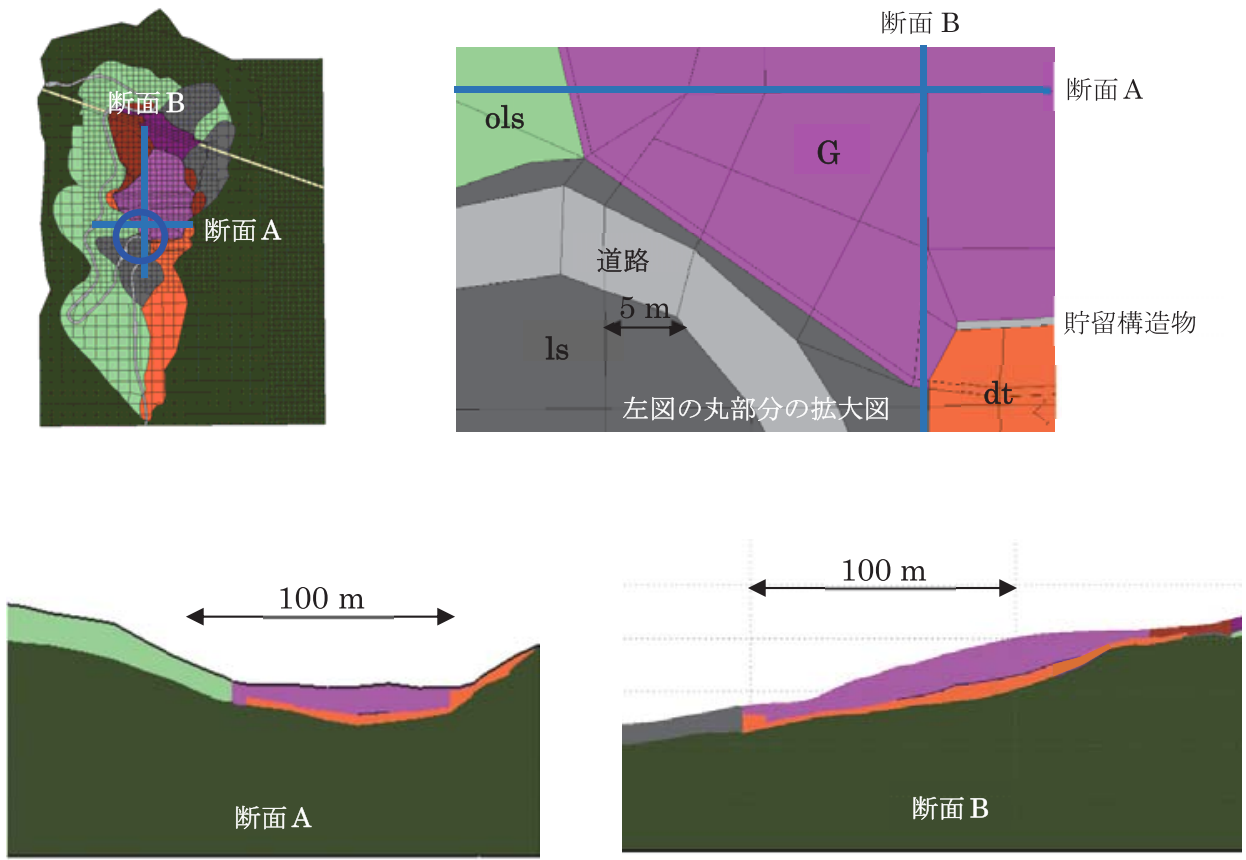

(b) 着目領域

図 6 非定常解析に抢ける入力降雨強度と着目領域

$\mathrm{m} / \mathrm{day}$ の降雨が生じたときの解析を実施した。着目地 点は, 図 6(b)に示すようにD 測線の左岸（下流から上 流を見た場合）から埋立地外への保有水等の流出をみる ための部分である。

恒久対策実施前の解析結果を図 7 に示す。この結果に 示されるように, 降雨が多くなり廃棄物層への浸透が増 えると, 左岸側への保有水等が埋立地外部に流出してし まうことがわかる。すなわち, イオン分析結果に示され たように図 8 のような埋立地外への保有水等の流出が生 じる。この埋立地外への流出は降雨が少ない状態では生 じて扔らず，常時の状態ではない。このことが一つの要 因となり, 現地調査でNo. 12 孔の地下水からは重金属
等の有害な物質は検出されていないと考えられる。

しかし，昨今は豪雨の生じやすい気候であり ${ }^{13)}$, こう した埋立地外への流出が常態化すれば, 廃棄物層に含ま れる重金属等の場外への漏えいが生じることが懸念され る。そこで，次に恒久対策工の効果を検討した。

\section{4 恒久対策工実施前後の解析結果}

対策工としては, 現行の保有水等をより多く排出する ことのできる集水井工を考えた。集水井工は, 遮水工を 新たに設ける場合に比べ施工性やコスト面で優れている こと, 新潟県は地すべり地が多く地すべり対策として地 元業者による集水井工が多く作られているという実績面 


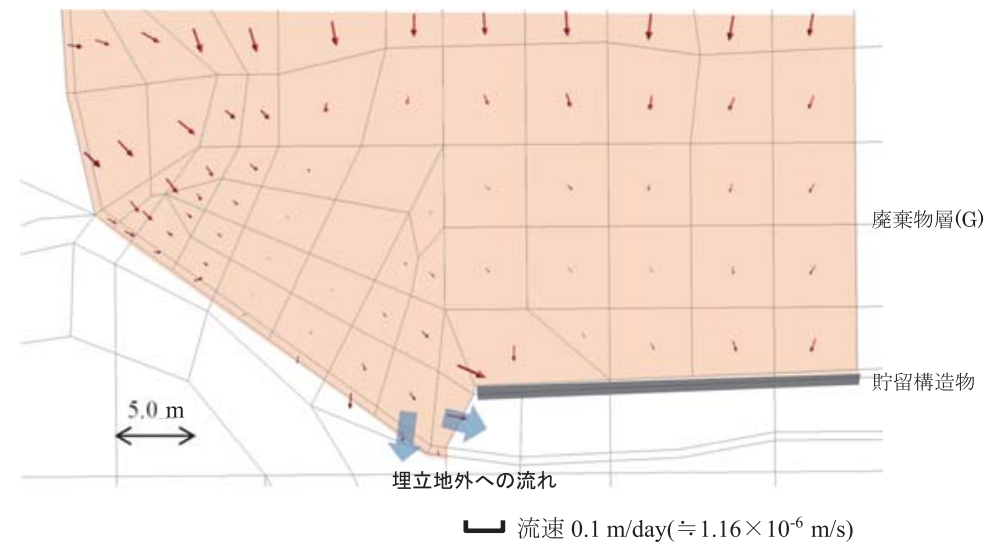

(a) 現況再現解析 Time: 4.0 日

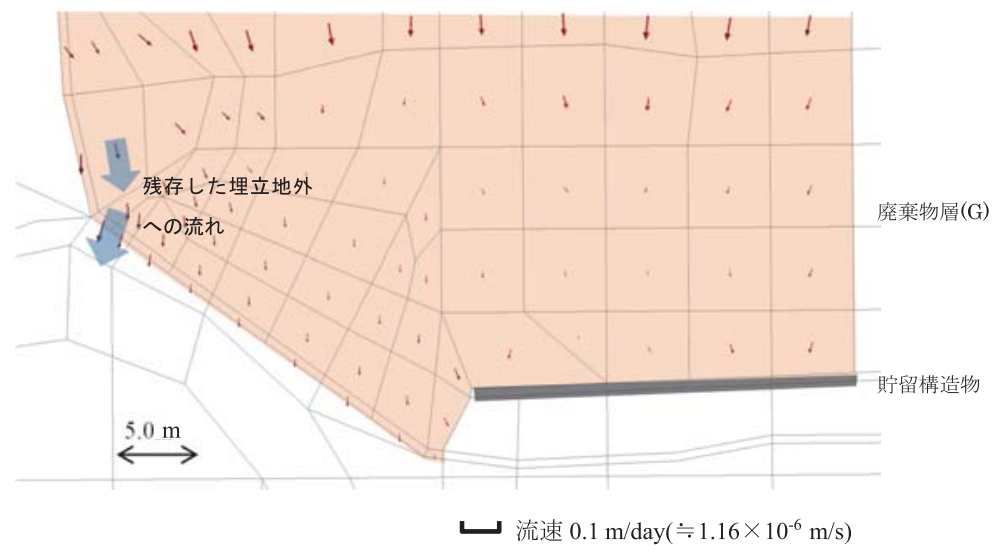

(b) 現況再現解析 Time: 10.0 日

飽和した廃棄物層 $(G)$ の最上部の要素の速度ベクトルのみを表示した図。一つの要素の平均速度ベクトルを表示

図 7 非定常による恒久対策実施前の地下水（保有水等）の流速ベクトル図

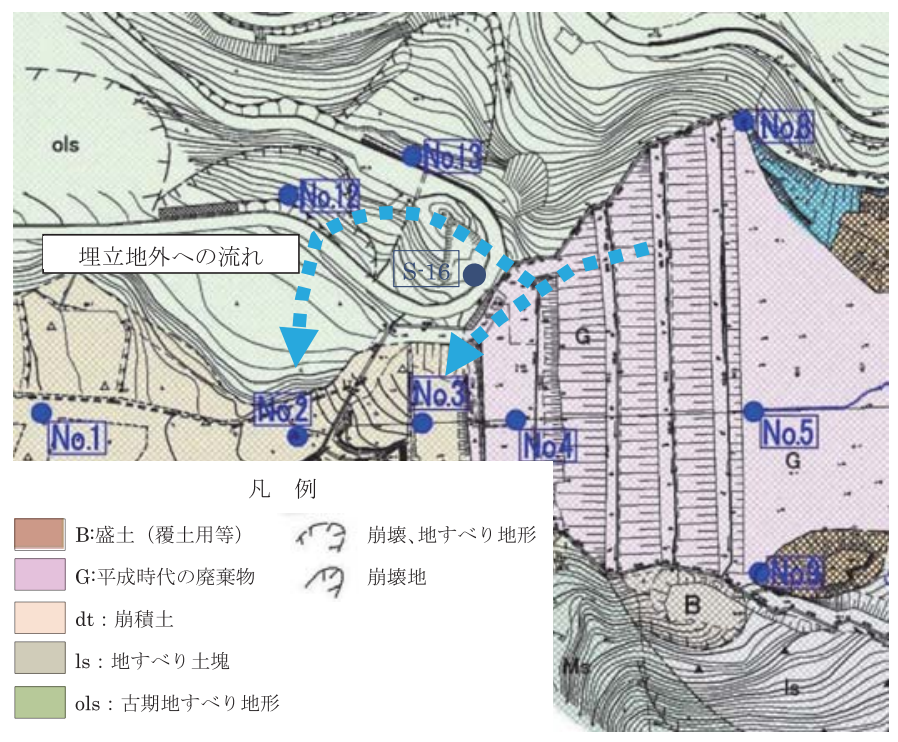

図 8 埋立廃棄物から埋立地外への流れの概念図 
や施工面の優位性等から，集水井工を選定した。

集水井工の配置は，いくつか検討したが，図 9 のよう に設定することを仮定すると，図 10 に示すような埋立 地外への流れを抑制する効果がみられる。

図 10 は泥岩層上面における圧力水頭分布図である。 集水井工実施前の圧力水頭分布図（図 10(a)）では，こ の最終処分場の貯留構造物である L 型擁壁の埋立側 (図の上側) の圧力水頭が $7 \mathrm{~m}$ 以上と高く, $\mathrm{L}$ 型擁壁の 左岸下流側の圧力水頭が $3 \mathrm{~m}$ 程度以下と低くなってい る。このことは, 図 7 に示したことと同様に, 地下水が 埋立地側から L 型擁壁左岸下流側へ流れやすい環境で あることを示している。

これに対して, 図 10（b）に示されるようにL 型擁壁 の上流の埋立地側の圧力水頭は $5 \mathrm{~m}$ 以下に低下し集水 井工設置前に比べて埋立地外への流出が起きにくい状況 となっていることを示している。この結果より, 集水井 工を左岸下流部を中心に設置することで大幅に埋立地内

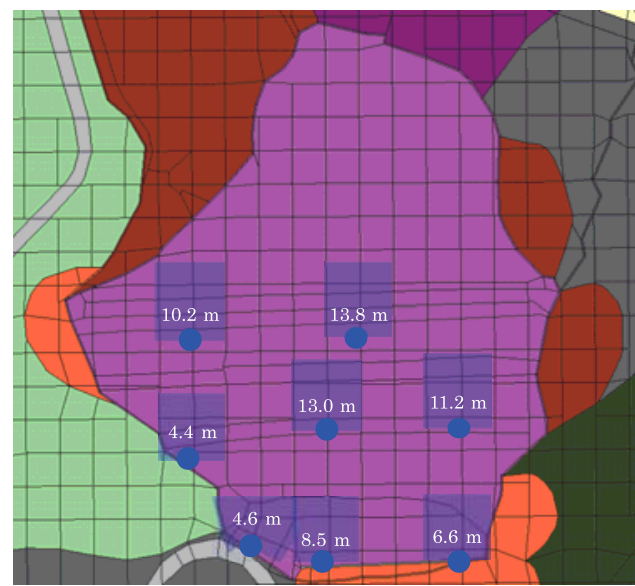

: 集水井（浸出面境界：井戸は地表から廃棄物層底面まで), 口: 水抜き (横) ボーリング範囲（表 2 の透水係数：設置深度 は廃棄物層底面), 図中の数值は集水井の深度 地層区分は，表 2 と同じ

図 9 恒久対策としての集水井工の配置モデル（最適解 の場合

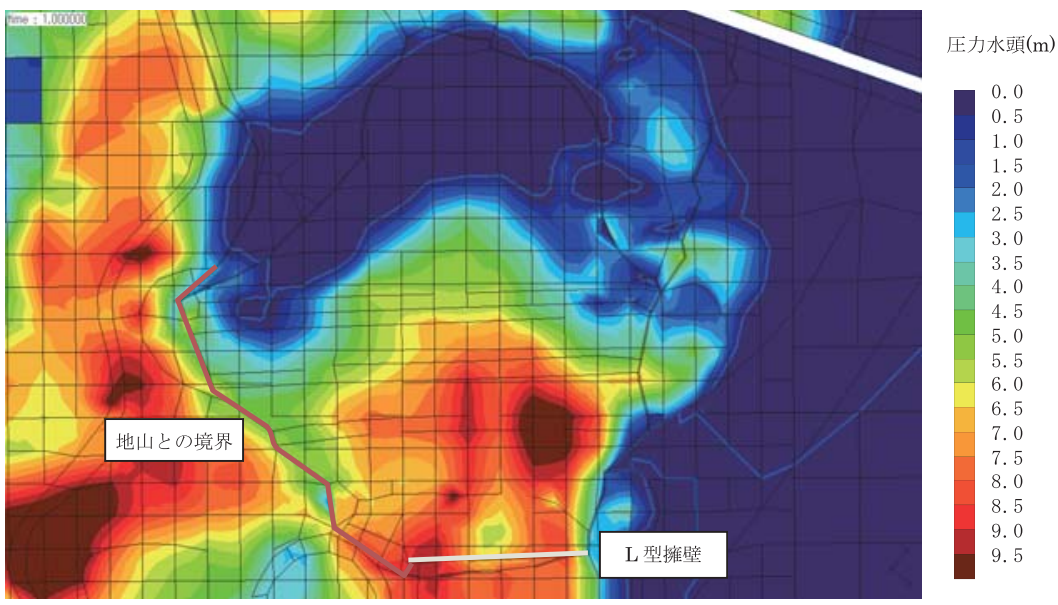

（a）恒久対策実施前の廃棄物層周辺の圧力水頭分布図（Ms 層上面）

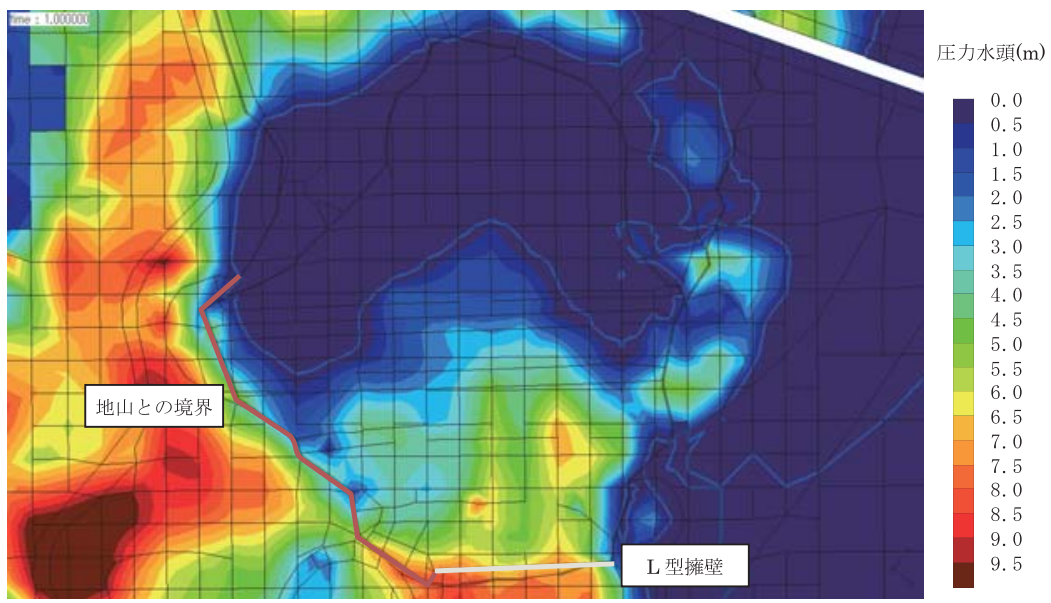

（b）集水井工を設置した場合の廃棄物層周辺の圧力水頭分布図（Ms 層上面）

図 10 対策工による廃棄物層内の圧力水頭分布の変化 
の保有水等を低減でき, 保有水等の埋立地外への流出が 起きにくい状況にできることがわかる。

集水井工 ${ }^{14)}$ は, 地すべりの地下水排除工として多用さ れる対策工であるが，地すべり土塊も廃棄物と同様に， 透水性の高いところと低いところが混在し, 全体として 小さな透水係数となる。この解析の地すべり土塊も $2.0 \times 10^{-7} \sim 5.0 \times 10^{-6} \mathrm{~m} / \mathrm{sec}$ と小さな值を示しているが, 一般的な地すべり土塊の透水係数である。一般に集水井 工は, こうした地すべり土塊中の地下水位を 3〜 $5 \mathrm{~m}$ 程 度低下できる可能性があり, 本解析結果からもその程度 の水位の低下が期待される。

以上の結果から, 集水井工の設置が有効であることが 示された。

\section{5. 保有水等の流出とウォーターバリア工法}

ここでは, 既設最終処分場の調査結果について, 周辺 環境の保全の観点から保有水等の埋立地外への流出の可 能性とその対策について考察する。

\section{1 保有水等の埋立地外への流出}

埋立地内の保有水等が埋立地外へ流出する場合がある ことは, FEM による三次元飽和・不飽和浸透流解析で 明らかにすることができた。この解析結果によれば，通 常は廃棄物層内から埋立地外に流出することはないが, 豪雨等の強い降雨強度を示す場合には流出が起きる。近 年は，国土交通省 ${ }^{13)}$ 等が示すように全国的に降雨強度の 強い雨が生じやすい傾向にあるが, 地域ごとに流量を変

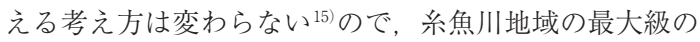

降雨を考えた設定は適切なものであると考えられる。し たがって, 解析モデルには保有水等集排水施設である暗 渠も設置していることから (表 2 参照), 数值解析の結 果は現状の集排水施設では十分に埋立地外への保有水等 の流出を防ぐことができないことを示している。以上の ことから, 現在は最終処分場の周辺環境を污染するよう な状況にはなっていないものの, 何らかの対策を施さな ければ将来的には廃棄物層に含まれる重金属等の有害物 質が周辺環境を污染する可能性のあることが示唆された。

これに対して，集水井工等を設置することで保有水等 の水位を下げ，保有水等の漏えいを防ぐことができるこ とも, 数值解析により示された。集水井工は, これまで 地すべり対策の地下水排除工として多く用いられてきた 対策工であるが, 地すべり土塊も廃棄物層と同様に, 透 水性の高いところと低いところが混在し, 平均的には透 水性は低い。そうした中で, 地下水排除工として実施さ れ，多くの実績を収めている。埋立廃棄物層においては あまり実績がないが, 今後, 有効に活用できるものと考 えられる。

一方, 破砕帯の存在については, 図 11 のような結果を 得た。この図に示されるように, 破砕帯に沿った埋立地 外への流れはみられず, 昭和時代の廃棄物から保有水等 が漏えいしている可能性は極めて低いものと考えられる。 この結果は, イオン分析の結果で不明確であった破砕帯 の影響を明らかにしたものであり,この破砕帯は水ミチ となっていないと考えられる。このことから, 昭和時代 の廃棄物は除去する必要がないことがわかり, 宮原ら ${ }^{2)}$ に示されるような残置が提案できる理由の一つとなる。

以上, 上述したように, 浸透流解析は, 他の調査結果

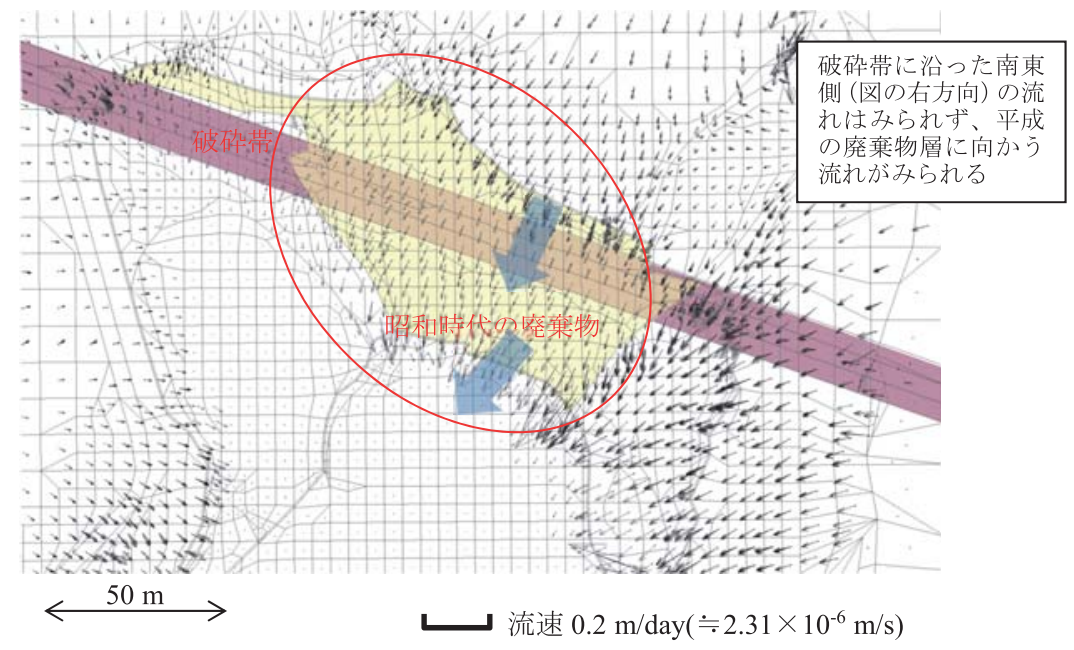

飽和した昭和時代の廃棄物層（oG）の最上部の要素の速度ベクトルのみを表示した図。一つの要素の平均速度ベクトルを表示

図 11 破砕帯が昭和時代の廃棄物層の直下にあると想定した場合の地下水流れ 
を裏づけるための資料として重要となることが改めて示 唆された。特に, 本調査地のような新旧の廃棄物層や地 すべり土塊, 破砕带のあるような比較的複雑な地形・地 質の場合には，二次元の浸透流解析ではなく三次元の非 定常浸透流解析を実施することで，保有水等の流れを明 らかにすることができる。近年は数值解析も進歩し, 比 較的安価に解析を実施することが可能となってきている ので, 数值解析が適正化事業においても多く実施される ことが望まれる。そのことによって，効果的な対策工を 提案することもできる。

\section{2 適正化恒久対策}

適正化応急対策実施後の恒久対策については, 以上示 した結果を考慮し，周辺環境の保全，特に保有水等の流 出の観点から，以下のような対応が必要と考えられる。

(1) 場内の恒久対策を実施するにあたり，周辺環境を 保全するために保有水等の有効な集排水システム
の構築が必要である。特に, 近年の豪雨傾向に対 する対策として，これは重要である。保有水等の 有効な集排水ができない場合, 保有水等の埋立地 外への流出が生じ, 将来的に周辺環境を污染する ことが懸念される。

(2) 保有水等の有効な集排水のためには, 現行の集排 水システム（暗渠である底面集排水設備等）だけ では対処できない。そのための適正化の方策とし て, 適切な数の集水井工等を設置し, その集水し た保有水等を処理施設へ配送するシステム等によ る積極的な保有水等の集排水システム（ウォー ターバリア工法）が必要である。

(3) ウォーターバリア工法により, 集排水する保有水 等の増大が予想される。したがって, 現状の保有 水等処理施設（調整槽含む）も増設する必要があ る。このため, 数值解析結果等を基に, 調整槽の 新設と水処理量 60 ton/日の増設（計 260 ton/日）

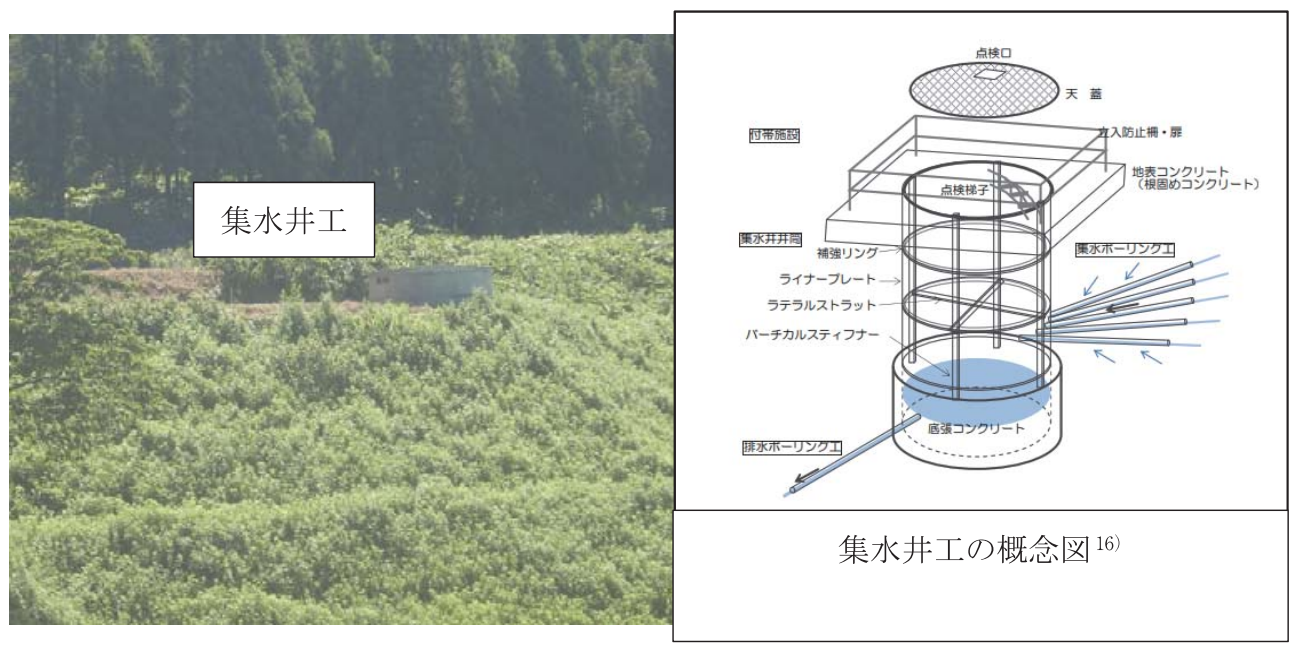

(a) 埋立地内の所々に設けられた集水井工 (2017 (平成 29) 年 6 月撮影)

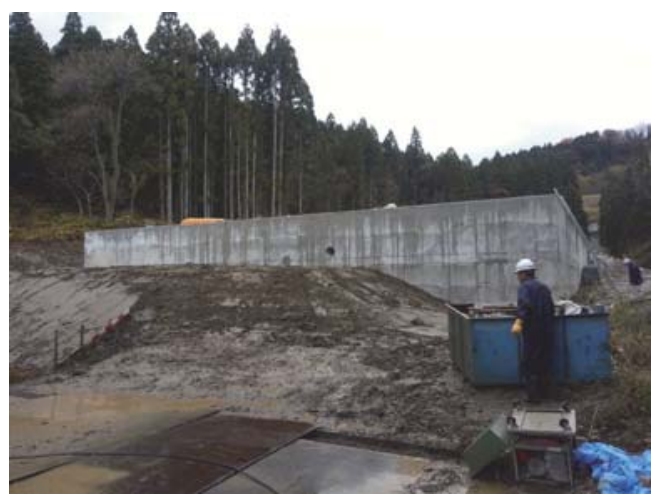

（b）増設された処理施設（調整槽）(2013 (平成 25) 年 11 月撮影)

図 12 糸魚川市一般廃棄物最終処分場の適正化事業の状況 
を行っている。

以上示した対策により，この最終処分場は適正化事業 が終了し，2016（平成 28）年 9 月にはその結果が糸魚 川市役所により公表されている。実際に，この最終処分 場は図 12 に示すように，集水井工が設置され，これら から集排水される保有水等を貯水するための貯留槽等の 水処理施設も規模を拡張して新たに設けられた。なお, 恒久対策後において，おおむね増設した水処理施設で十 分な機能を発揮したことを付記しておく。

これらの適正化恒久対策により, この最終処分場は 2016 (平成 28) 年 2 月に適正化事業を完了し, 2016 (平 成 28）年度に埋立処分終了届を提出，2018（平成 30）年 4 月に廃止となった。なお，その後も集水井からの集排 水は継続している。

\section{3 ウォーターバリアエ法の有用性}

埋立廃棄物層内の保有水等の水理ポテンシャルが高い 場合, その保有水等の埋立地外への流出を防ぐために, 図 13 に示すようなウォーターバリア工法が有用である。 ウォーターバリア工法は, 埋立廃棄物層内に新設する集 水井工等の縦集排水施設等, 保有水等の水理ポテンシャ
ルを低減させるための施設と, 集水量が増大する場合に は水処理施設を増設することからなる工法である。

ウォーターバリア工法は, 集水井工等の縦集排水施設 により，埋立地内部の水理ポテンシャルを下げるが，周 辺の地山の水理ポテンシャルは大きくは変化しないため, 水理ポテンシャルに伴う流れ（流線）の方向を埋立地外 から埋立地内へと変えるものである。これにより周辺地 山が元々もっている地下水をバリアとし, 流出を防ぐこ とができる。これは，対策マニュアル案の示す地下水制 御工法に分類される。

この工法の利点は, 鉛直遮水工等を新設するのに比べ, 施工性やコスト面で比較的優れている点である。たとえ ば，この対象最終処分場の場合，埋立地の周囲に鉛直遮 水工を設置するのであれば, 数億円の直工費が必要とな るが, ウォーターバリア工法の場合, 集水井工の直工費 は数千万円で納まる。また, 集水井工であれば地元業者 でも十分に施工可能である。地形・地質状況によって異 なると思われるが，この工法は比較的優れた工法と考え られる。

本来, 遮水工は, 完全に不透水 (透水係数 $0 \mathrm{~m} / \mathrm{sec}$ ) にすることはできず，場合によっては数十年・数百年と

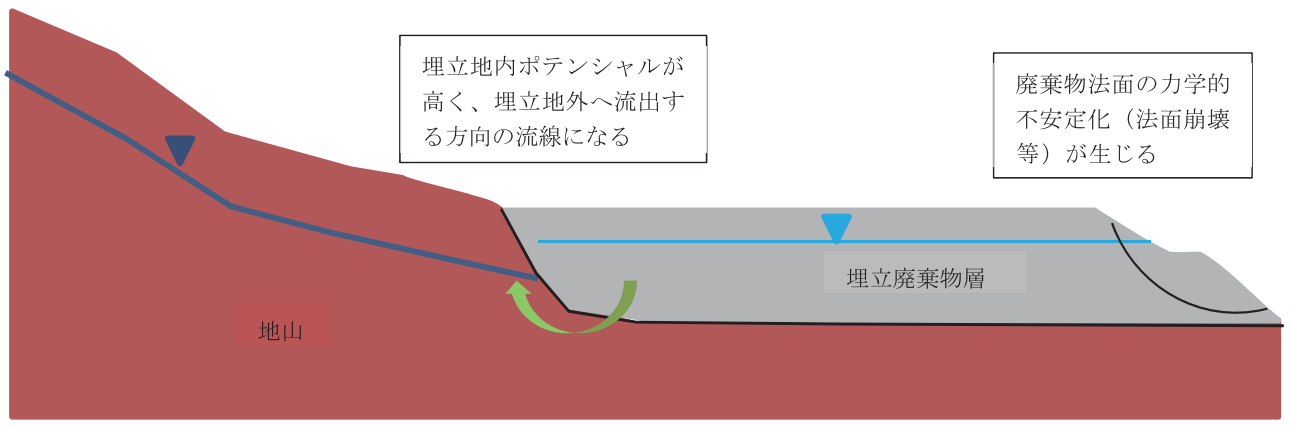

（a）埋立地内の保有水等の水位の高い不適正状態

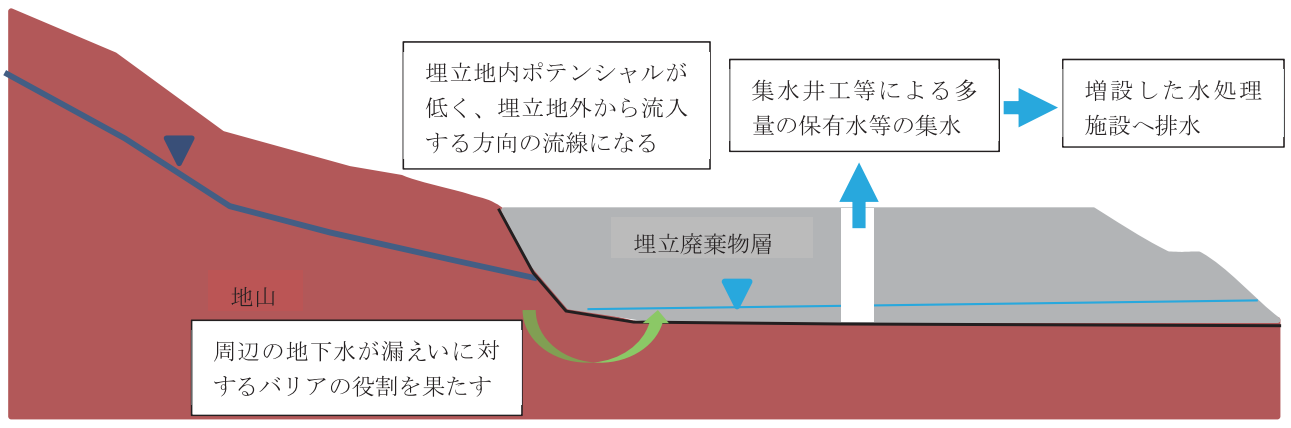

（b）ウォーターバリア工法の対策実施後

遮水工の有無にかかわらず，埋立廃裹物層内の水理ポテンシャルが周辺地山の地下水より低ければ，埋立地内に流入する方向の流線 （図中のU）となる。すなわち, 周辺の地下水（ウォーター）が漏洩に対するバリアの役割を果たす。これにより，基準省令の要求す る「埋立地からの浸出液による公共の水域㧍よび地下水の污染を防止する」ことができる。集水井工等により集水した保有水等を自然 流下させる方法をとれば，廃止後も保有水等を集水できるので，集水井工等の維持管理さえ行えば，半永久的にバリア効果がある

図 13 ウォーターバリア工法の概念図 
時間はかかるものの，浸出していく（ただし，その長い 時間内で有害物質の拡散や吸着等による遅延等により, 保有水等の有害性は低下する傾向にある)。これに対し て, ウォーターバリア工法では, 水理ポテンシャルが埋 立地内よりも周辺の地山のほうが高いので, 周辺から埋 立地内に流入する方向にしか作用しない。すなわち, 遮 水工の有無にかかわらず, 数十年・数百年たっても, 水 理ポテンシャルの低い状態が維持されていれば埋立地外 へ保有水等が流出することはない (図 13 参照)。

さらに, この工法は, 保有水等の水理ポテンシャルの 低減が, 埋立廃棄物層で形成された盛土の力学的安定性 の確保にも有効であることが利点としてあげられる。水 位が高くなる，あるいは高含水になることは，宮原ら ${ }^{2)}$ や大野ら ${ }^{17)}$ 等が指摘するように埋立廃棄物の崩壊等の力 学的不安定化を引き起こす。特に, 近年は埋立廃棄物の 盛土高さも数十 $\mathrm{m}$ 程度に及ぶ場合があり, 留意すべき 点である。

このように, ウォーターバリア工法は次の点で優れて おり, 今後の適正化事業において有用な対策工法の一つ になると考えられる。

(1) 安価で優れた施工性：地元業者でも施工が可能な ほど施工性が良いとともに，一般的土木工事のた め安価な施工が可能。

(2) 比較的容易で安価な維持管理：地形を利用した自 然流下を基本とした設計が可能であり, 維持管理 が容易で安価。

(3) 広い範囲の保有水等の集水が可能: 集水井工は, 通常水抜きボーリングを併用するので, 広い範囲 から集水可能。

(4) 力学的安定性の確保にも効果: 保有水等の水位を 下げることで法面崩壊防止等の力学的安定性の確 保にも効果あり。

\section{6.おわりに}

最終処分場は忌避される施設の一つであるが, 適正に 設置・維持管理されれば，環境保全機能に優れており， 低コスト, 低エネルギー消費, 低環境リスクな施設 ${ }^{18)}$ で ある。元々低コストな最終処分場において, 不適正な状 態を改善するために収支が見合わない対策を実施するこ とはあまり現実的ではない。より低コストで施工性の良 い適正化対策が重要であり, そのためには, 適切な現況 調査を行い適正化に向け地質工学的にも有効な対策を行 う必要がある。ここでは, 適正化にあたって問題となっ た保有水等の流出の観点からの調査とその結果を示し, 適正化対策としてウォーターバリア工法について論じた。
その結果，以下のことが示された。

(1) イオン分析や物理探査等で不明確であった保有水 等の埋立地外への流出を, 三次元浸透流解析を併 用することにより，明らかにすることができた。 このことは, 基本的に地質工学的手法の重要性を 示したものである。

(2) 漏えいによる有害物質等の污染を防止するために, 集水井工等を用いる新たなウォーターバリア工法 を実施することの有効性を数值解析等により示す ことができ，その設置が実際に行われた。

(3) ウォーターバリア工法は, 埋立廃棄物層内の集排 水施設の増設と, 集水量の増大に伴う水処理施設 の増設を行うことなどにより, 周辺地下水よりも 埋立地内の水理ポテンシャルを積極的に低くする 工法であり，施工性やコストの面で比較的優れて いるだけでなく, 埋立廃棄物層の力学的安定性に も有効である。

ここに示した情報が, 今後の最終処分場の適正化事業 に役立ってくれれば幸いである。

最後に, 本論をまとめるにあたり, 快諾をしてくだ さった新潟県系魚川市役所の方々に深謝の意を表する。 また，調査等にあたってご協力いただいた関係各位に謝 意を表する。

\section{参 考文 献}

1) 大野彰久 $\cdot$ 瀬尾英孝 $\cdot$ 島岡隆行 : 不適正最終処分場に 係る支障等除去対策事例について, 第 26 回廃棄物資源 循環学会研究発表会講演集, D1-4, pp. 399-400 (2015)

2 ）宮原哲也 - 八村智明 - 大野博之 - 小坂英輝 $\cdot$ 大久保拓 郎・山内一志・山中 稔: 最終処分場の適正化に向けた 調査と対策 I — 主に力学的安定性の観点から—, 廃棄物資源循環学会論文誌, 第 29 巻, pp. 206-218 (2018)

3) 渡辺洋一：廃棄物不適正処分現場における環境修復技 術, 廃棄物資源循環学会誌, 第 20 巻, 第 6 号, pp. 304307 (2009)

4) 不適正処分場における土䁃污染防止対策検討委員会: 不適正処分場に打ける土壤污染防止対策マニュアル (案), 平成 19 年 3 月, p. 32 (2007)

5) NPO 法人 最終処分場技術システム研究協会: 廃棄物 最終処分場新技術ハンドブック， p. 460（2006）

6 ) 糸魚川市: 糸魚川市一般廃棄物最終処分場適正化事業 の経過と再発防止対策，平成 28 年 9 月, p. 50 (2016)

7 ) 小島圭二 · 大塚康範 · 大野博之 ·軽部文雄 $\cdot$ 土屋彰 義・德永朋祥: 東京湾岸地域に扔ける地質工学— 50 年の実績, 応用地質, 第 50 卷, 第 3 号, pp. 70-78 (2009)

8) (公社)物理探查学会：物理探査ハンドブック 増補改訂版 
第二分冊，第 7 章 電気探査, pp. 367-433（2016）

9 ) (財法)国土開発技術研究センター：地下水調査および観 測指針 (案), 山海堂, p. 330 (1993)

10） (公社) 地盤工学会編：地盤調查の方法と解説 — 二分 冊の 1 一, 第 7 編 地下水調查, 第 7 章 地下水流動 状況の調査, pp. 615-659 (2013)

11）たとえば，全国都市清掃会議偏：廃棄物最終処分場整 備の計画 · 設計 ·管理要領— 2010 改訂版, II 編 設 計要領, 3 章 貯留構造物, pp. 199-224（2010）

12）社地盤工学会：地盤調查法, 第 7 編 地下水調查, 第 2 章 ボーリング孔を利用した砂質地盤の地下水位測定, pp. 271-275 (1995)

13）国土交通省：国土交通省白書 2017, 第 II 部 第 7 章 安 全·安心社会の構築, 第 2 節 自然災害対策, pp. 231-
259 (2017)

14）たとえば, 日本道路協会編：道路土工——切土工・斜 面安定工指針 (平成 21 年度版), 第 11 章地すべり対策, pp. 369-438 (2009)

15）国土交通省水管理 - 国土保全局：浸水想定（洪水, 内 水) の作成等のための想定最大外力の設定手法, 平成 27 年 7 月, p. 43 (2015)

16）農林水産省：地すべり防止施設の機能保全の手引き — 総合版, 平成 29 年 3 月 (2017)

17）大野博之・磯部有作・稲垣秀輝：最終処分場における 斜面問題の考え方に関する一考察, 第 12 回環境地盤工 学シンポジウム講演論文集, pp. 35-40（2017）

18）田中信寿：最終処分場の基本的設計理念, 都市清掃, 第 51 巻, 第 225 号, pp. 11-14 (1998)

\title{
Geological Engineering Survey/Evaluation and Countermeasure for Final Disposal Site Improvement Part 2 :
}

Leachate from Landfill

\author{
Tetsuya Miyahara*, Tomoaki Hachimura*, Hiroyuki Ohno**, Hideki Kosaka**, Ken-ichi Hosono*** \\ Kazuyuki Yamauchi* and Minoru Yamanaka**** \\ * West Branch, Japan Environmental Sanitation Center \\ ** Kankyo-chishitsu Co., Ltd. \\ *** Subsurface Environment Project Group, Geoscience Research Laboratory \\ ***** Faculty of Engineering and Design, Kagawa University \\ ${ }^{+}$Correspondence should be addressed to Hiroyuki Ohno: \\ Kankyo Chishitsu Co., Ltd. \\ (4-15-203 1-Chome, Kaizuka, Kawasaki-ku, Kawasaki 210-0014, Japan)
}

\begin{abstract}
The problems of geological engineering surveys and evaluations for improvement of final disposal sites have been noticed from the view of environmental conservation. Waste containing mercury exceeding the standard was landfilled in the Itoigawa final disposal site. To improve this final disposal site, we carried out several geological-engineering surveys, including geophysical prospecting and numerical analysis of groundwater.

The results of surveys and numerical analysis showed that internal water containing arsenic and other harmful heavy metals might leak from the landfill site with heavy rain. Therefore, if drainage wells are provided in landfill sites, they would not only act as an effective countermeasure for environmental conservation as water barriers, according to the results of our numerical analysis, but they would also effectively contribute to the mechanical stability of the landfill. This water barrier countermeasure uses a method in which the hydraulic potential of the internal water in the landfill is lower than that of the groundwater in natural ground around the landfill. For an example, there are several drainage wells (with drainage bore holes) and water treatment facilities. This countermeasure is inexpensive with good workability.
\end{abstract}

Keywords : fnal disposal site, geological engineering survey and evaluation for adjustment, geophysical prospecting, numerical simulation, water barrier countermeasure work 